\title{
PENELITIAN PEMBUATAN ETANOL DARI SERAT/AMPAS SAGU
}

\author{
RESEARCH MAKING ETHANOL FROM FIBER / PULP SAGO \\ Fahri F. Polii \\ Balai Riset dan Standardisasi Industri Manado \\ Jalan Diponegoro No: 21-22 Manado \\ e-mail: poliifahri@yahoo.com \\ Diterima tgl 19-05-2016, Disetujui tgl 27-05-2016
}

\begin{abstract}
ABSTRAK
Penelitian pembuatan etanol dari serat/ampas sagu baruk dan sagu rumbia telah dilakukan. Penelitian ini bertujuan untuk mendapatkan etanol dari serat/ampas sagu dengan perlakuan proses hidrolisis asam dan lama proses hidrolisis. Bahan yang digunakan dalam penelitian ini berupa serat/ampas sagu baruk (Arenga microcarpa Beccari) dan sagu rumbia (Metroxylon sagu) yang merupakan limbah dari proses pengambilan tepung pati sagu. Serat/ampas sagu dipersiapkan melalui proses pengeringan, pengilingan, pengayakan hingga diperoleh serbuk berukuran 40 mesh. Sebelum digunakan sebagai bahan baku pembuatan etanol, terhadap serat/ampas sagu yang telah disiapkan dianalisis untuk mengetahui kadar karbohidrat dan gula. Hasil uji bahan baku menunjukkan kadar karbohidrat serat/ampas sagu baruk dan sagu rumbia adalah $41,22-$ $49,18 \%$ dan 52,78-62,85\%, sedangkan kadar gula bahan baku adalah 1,91-3,19\% dan 1,28-3,19\%. Selanjutnya ke dalam bahan baku yang telah disiapkan ditambahkan asam sulfat dengan konsentrasi 0,5 $\mathrm{N} ; 1,0 \mathrm{~N} ; 1,5 \mathrm{~N}$ dan dihidrolisis selama 2, 3, dan 4 jam pada temperatur $121^{\circ} \mathrm{C}$. Hasil analisis menunjukkan bahwa kadar gula serat/ampas sagu dipengaruhi oleh konsentrasi asam sulfat yang ditambahkan serta lama proses hidrolisis pada temperature $121^{\circ} \mathrm{C}$. Kadar gula tertinggi ditemukan pada serat/ampas sagu rumbia dengan perlakuan penambahan asam sulfat 1,5 $\mathrm{N}$ yang dihidrolisis selama 3 jam, yakni 13,90\%. Kadar etanol tertinggi juga diperoleh pada hasil fermentasi serat sagu rumbia yang diperlakukan dengan penambahan asam sulfat $1,0 \mathrm{~N}$ yang dihidrolisis selama 3 jam, yakni $13,60 \%$. Limbah pengolahan pati sagu dari tanaman sagu baruk dan sagu rumbia berupa serat/ampas dapat diolah menjadi etanol melalui proses hidrolisis asam sulfat konsentrasi rendah dengan pemanasan bertekanan.
\end{abstract}

Kata Kunci: etanol, serat, sagu, konsentrasi, hidrolisis

\section{ABSTRACT}

Research making ethanol from fiber / pulp of sago baruk and sago palm has been done. This study aims to obtain ethanol from fiber / pulp sago treated with some different sulfuric acid concentrations and a long process of hydrolysis. Materials used in this study were fiber / pulp of sago baruk (Arenga microcarpa Beccari) and sago palm (sago Metroxylon) which is a waste of sago starch-making process. Sago fiber / pulp was prepared through the process of drying, milling, and sieving to obtain a powder size of 40 mesh. Before being used as a raw material for making ethanol, sago fiber / pulp were analyzed to determine levels of carbohydrates and sugar. The test results showed that levels of carbohydrate of both raw materials used were 41.22 to $49.18 \%$ for sago baruk and 52.78 to $62.85 \%$ for sago palm, while the sugar content were $1,91-3.19 \%$ and 1.28 to $3.19 \%$, respectivelly. Further to the raw materials that treated with sulfuric acid concentration of 0.5 $\mathrm{N} ; 1.0 \mathrm{~N} ; 1.5 \mathrm{~N}$ and hydrolyzed for 2,3 , and 4 hours at temperatures of $121^{\circ} \mathrm{C}$ were show the results that the highest sugar content was resulted in the sago fiber / pulp that treated with the addition of $1.5 \mathrm{~N}$ sulfuric acid and hydrolyzed for 3 hours yields $13.90 \%$. The same result also obtained in ethanol content for sago palm fibers that are treated with the addition of $1.0 \mathrm{~N}$ sulfuric acid and hydrolyzed for 3 hours yields $13.60 \%$. Waste processing sago from sago starch and sago baruk in the form of fiber / pulp could be processed into ethanol through a process of low concentration of sulfuric acid hydrolysis with pressurized heating.

Keywords: ethanol, fiber, sago, concentration, hydrolysis 


\section{PENDAHULUAN}

Indonesia memiliki sumber daya alam melimpah. Salah satu kekayaan alam Indonesia adalah tumbuhan sagu (Metroxylon sp.). Luas areal tanaman sagu di Indonesia diperkirakan 1.114.000 hektar yang merupakan 50 persen dari total luas areal sagu dunia[1]. Luas areal sagu yang sudah dibudidayakan baru sekitar 114.000 hektar, sedangkan lahan sagu seluas 1.000 .000 hektar belum dibudidayakan secara intensif. Sagu dapat tumbuh di daerah rawa atau tanah marginal yang sulit ditumbuhi oleh tanaman penghasil karbohidrat lainnya[5]. Sagu memiliki kandungan pati yang besar. Pada umur panen sagu sekitar 11 tahun ke atas empulur sagu mengandung $15-20$ persen pati[6].

Potensi sagu yang besar ini belum di eksploitasi secara optimal. Sangat rendahnya pemanfaatan areal sagu dalam bidang pangan yang hanya sekitar $10 \%$ dari total areal sagu nasional disebabkan oleh kurangnya minat masyarakat dalam mengelola sagu[2]. Potensi sagu Indonesia merupakan yang terbesar di dunia dan dapat dimanfaatkan dalam industri energy [4].

Ampas sagu merupakan limbah yang dihasilkan dari pengolahan sagu, kaya akan karbohidrat dan bahan organik lainnya. Pemanfaatannya masih terbatas dan biasanya dibuang begitu saja ke tempat penampungan atau ke sungai yang ada di sekitar daerah penghasil. Oleh karena itu ampas sagu berpotensi menimbulkan dampak pencemaran lingkungan[7]. Ampas sagu merupakan salah satu jenis limbah perkebunan yang didapatkan pada proses pengolahan tepung sagu. Perbandingan tepung dengan ampas yang dihasilkan pada pengolahan tepung sagu adalah sekitar 1:6[8]. Dalam pengolahan empulur sagu diperoleh $18,5 \%$ pati dan $81,5 \%$ berupa ampas[9]. Ampas sagu terdiri dari serat-serat empulur yang diperoleh dari hasil pemarutan/pemerasan isi batang sagu. Limbah ampas merupakan bahan lignoselulosa yang sebagian besar tersusun atas selulosa, hemiselulosa, dan lignin. Ampas sagu dapat digunakan untuk berbagai keperluan diantaranya sebagai pakan ternak, etanol dan bioethanol.

Pembuatan etanol dari pati dapat dilakukan secara kimia ataupun biologis.. Etanol dapat diperoleh dari serat dengan menggunakan enzim selulase dan asam. Efektivitas proses ini dipengaruhi oleh jenis enzim, kekentalan bahan (ratio pati dan air), presentase enzim, konsentrasi asam dan proses fermentasi. Pembuatan etanol menggunakan $\mathrm{NaOH}$ dan $\mathrm{NH}_{4} \mathrm{OH}$ diperoleh rendemen etanol 12,99\% sebesar 0,38 $\mathrm{mL}$ pada lama fermentasi 168 jam[8]. Penggunaan enzim selulosa dalam pembuatan etanol dari sagu diperoleh konsentrasi etanol tertinggi yaitu $8 \%$ pada saat konsentrasi substrat $80 \mathrm{gr}$ dan volume inokulum 12,5\%[12].

Fermentasi alkohol atau alkoholisasi adalah proses perubahan gula menjadi alkohol dan $\mathrm{CO}_{2}$ oleh mikroba, terutama oleh khamir Saccharomyces cerevisiae. Kualitas 
hasil fermentasi bahan secara biologis diantaranya tergantung pada ketersediaan energi dan nutrient lain bagi pertumbuhan mikroba[10].

Dari data-data di atas menunjukkan bahwa potensi tanaman sagu sangat tinggi akan tetapi belum dimanfaatkan secara maksimal. Salah satu potensi yang belum dimanfaatkan yakni ampas sagu yang merupakan limbah dalam proses pengolahan pati/tepung sagu dan ternyata mengandung selulosa yang tinggi dan dapat ditingkatkan menjadi produk yang bernilai ekonomis yakni etanol (bioetanol) dimana proses dapat dilakukan secara kimia.

Penelitian ini bertujuan untuk mendapatkan etanol dari serat/ampas sagu dengan proses hidrolisis asam dan lama pemanasan.

\section{BAHAN DAN METODE}

\section{Bahan dan Alat}

Bahan utama yang digunakan dalam penelitian ini yaitu: ampas/serat sagu, asam sulfat, natrium hidroksida, ragi roti fermipan, minyak tanah/gas elpiji, dan bahan kimia untuk analisis. Alat yang digunakan yaitu: autoklaf, alat penghancur serat (dish mill), fermentor, alat suling alkohol, kompor, erlenmeyer, beker gelas, hand refraktometer, piknometer, alkohol meter, $\mathrm{pH}$ meter, neraca, oven, penyaring dan alat uji kimia/laboratorium.

\section{Metode Penelitian}

Penelitian ini dilaksanakan dalam beberapa tahap yaitu:

\section{Tahap I. Persiapan Bahan Baku}

Pada tahap ini bahan baku serat /ampas sagu diperlakukan penggilingan dengan tujuan untuk mencari tingkat kehalusan bahan baku yang akan diproses sehingga didapatkan kadar karbohidrat dan kadar gula tertinggi. Adapun tingkat kehalusan yang diperlakukan yakni 4 mesh dan 40 mesh. Tahap ini menggunakan metode deskriptif dan hasil perlakuan terbaik tahap 1 menjadi dasar untuk penelitian selanjutnya.

\section{Tahap 2. Penambahan Larutan Asam Sulfat, hidrolisis dan fermentasi}

Tahap ini dilakukan untuk melihat pengaruh penambahan asam sulfat dengan beberapa konsentrasi yakni $0,5 \mathrm{~N}, 1,0 \mathrm{~N}$ dan 1,5 N untuk hidrolisis dengan metode panas dan bertekanan serta lama hidrolisis 2 jam, 3 jam, dan 4 jam dengan 2 ulangan. Tahap ini menggunakan metode deskriptif.

\section{Tahap 3. Destilasi etanol}

Pada tahap ini dilakukan destilasi alkohol untuk mendapatkan kadar etanol tertinggi dari hasil perlakuan pada tahap 2. Tahap ini menggunakan metode deskriptif.

\section{Prosedur Penelitian}

a. Serat sagu dipisahkan dari
kotoran/benda bukan serat sagu
kemudian Serat sagu dihaluskan


dengan menggunakan dish mill,

b. dilakukan uji karbohidrat dan gula.

c. Serat sagu ditimbang sejumlah 75,0 gram lalu dimasukkan dalam Erlenmeyer, ditambahkan $750 \mathrm{ml}$ larutan asam sulfat $0,5 \mathrm{~N}$.

d. dimasukkan ke dalam autoclave dan dipanaskan pada suhu $121^{\circ} \mathrm{C}$ selama (120 menit) dengan tekanan $76 \mathrm{cmHg}$ untuk proses hidrolisis, kemudian hasil hidrolisis dinetralkan dengan larutan $\mathrm{NaOH} 20 \%$ hingga $\mathrm{pH}$ 5, lalu diukur volume larutan/hidrolisat dan dilakukan uji kadar gula.

e. Larutan/hidrolisat disaring lalu ditambahkan ragi roti (Fermipan) 3\%, kemudian medium fermentasi ditutup dengan kertas kraft dan dimasukkan ke dalam fermentor selama 24 jam f. Setelah 24 jam, larutan/cairan hasil fermentasi dilakukan penyulingan/destilasi untuk memisahkan air dan etanol, kadar etanol diuji (piknometer), dan dihitung rendemen.

Diagram alir proses pembuatan etanol dari limbah serat/ampas sagu tercantum pada gambar 1. 

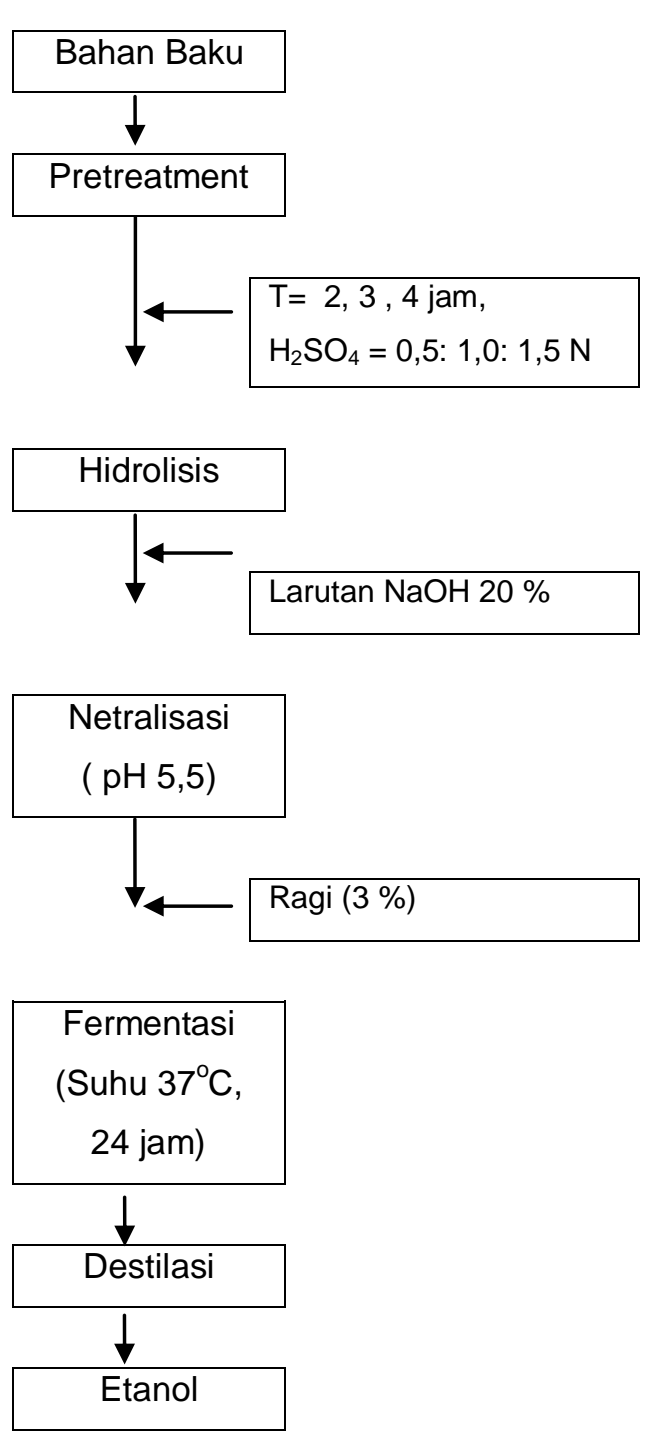

Gambar 1. Diagram alir pembuatan etanol dari ampas/serat sagu

\section{Pengamatan}

Pengamatan dilakukan terhadap kadar karbohidrat dan kadar gula bahan baku serat/ampas sagu baruk dan sagu rumbia, volume larutan hasil hidrolisis, kadar gula larutan hasil hidrolisis, volume destilat (etanol), kadar etanol dan rendemen

\section{Analisis Data}

Data yang diperoleh ditabulasi dan disusun dalam bentuk tabelaris.

\section{HASIL DAN PEMBAHASAN}

\section{Kadar Karbohidrat dan Gula Serat Sagu}

Hasil uji kadar karbohidrat dan gula dengan berbagai ukuran kehalusan serat sagu tercantum pada tabel 1 di bawah ini.

Tabel 1. Hasil uji kadar karbohidrat dan Gula

\begin{tabular}{lllll}
\hline No & Jenis serat sagu & Ukuran serat & Karbohidrat (\%) & Gula (\%) \\
\hline 1 & Sagu Baruk & Kasar (4 mesh) & 41,22 & 1,91 \\
2 & Sagu Baruk & Halus (40 mesh) & 49,18 & 3,19 \\
3 & Sagu rumbia & Kasar (4 mesh) & 52,78 & 1,28 \\
4 & Sagu rumbia & Halus (40 mesh) & 62,85 & 3,19 \\
\hline
\end{tabular}


Hasil analisis kadar karbohidrat dan gula dengan 2 jenis serat sagu dengan berbagai ukuran menunjukkan bahwa jenis serat dan ukuran kehalusan serat sagu memberikan perbedaan hasil terhadap kadar karbohidrat dan kadar gula. Kadar karbohidrat tertinggi diperoleh pada serat sagu rumbia dengan kehalusan 40 mesh yakni 62,85\%, sedangkan kadar karbohidrat terendah pada serat sagu baruk yaitu $41,22 \%$. Sebaliknya untuk kadar gula ternyata serat sagu baruk cenderung lebih tinggi dibandingkan serat sagu rumbia pada ukuran kehalusan kasar (4 mesh) yakni 1,91\% (sagu baruk) dan 1,28\% (sagu rumbia). Akan tetapi pada kehalusan serat 40 mesh kadar gula kedua jenis serat ini sama yakni $3,19 \%$. Tingginya kadar karbohidrat pada serat sagu rumbia dipengaruhi oleh beberapa factor diantaranya adanya pati (karbohidrat) yang tidak terekstrak ketika proses ekstraksi sagu dan tertinggal pada serat/empulur sagu (limbah). Hal ini dapat terjadi karena proses ekstraksi dari serat/empulur sagu rumbia dilakukan secara tradisional (contoh dari proses ekstraksi/pencucian menggunakan tangan manusia). Pada proses ekstraksi sagu baruk menggunakan alat mesin ekstraksi, diduga karena menggunakan mesin, maka proses ekstraksi/pencucian pati dalam serat lebih maksimal juga alat bekerja secara kontinu sehingga pati/karbohidrat yang tertinggal dalam serat sagu baruk sedikit).

Kadar gula serat sagu baruk dan serat rumbia cenderung berbeda pada ukuran serat ( ukuran 4 mesh) akan tetapi sama pada kehalusan 40 mesh. Adanya perbedaan kadar gula pada ukuran serat kasar (4 mesh) dipengaruhi oleh beberapa faktor antara lain pada serat yang halus ( 40 mesh) proses hidrolisis karbohidrat menjadi gula sederhana labih mudah karena penetrasi asam $\left(\mathrm{H}_{2} \mathrm{SO}_{4}\right)$ ke dalam butiran/serbuk serat lebih maksimal dibandingkan denga keadaan serat yang kasar dan dengan sendirinya proses perubahan karbohidrat menjadi gula akan maksimal, sebaliknya pada ukuran serat kasar (butiran kasar) penetrasi asam ke dalam serat tidak maksimal karena diameter serat yang besar dan diduga tidak semua bagian serat di penetrasi oleh asam yang akan merubah karbohidrat menjadi gula sederhana.

Berdasarkan hasil uji terhadap kadar karbohidrat dan gula serat sagu dengan berbagai ukuran dan ternyata serat yang dihaluskan sampai dengan 40 mesh memberikan kadar tertinggi, maka untuk perlakuan selanjutnya menggunakan serat sagu dengan ukluran 40 mesh.

\section{Volume Larutan Hidrolisis serat Sagu}

Serat sagu dengan ukuran 40 mesh setelah dihidrolisis, maka dilakukan pengukuran volume larutan yang diperoleh dan dapat dilihat pada Tabel 2. Volume awal $750 \mathrm{ml}$ (asam sulfat yang ditambahkan pada 75 gram contoh serat sagu) setelah melalui proses hidrolisis dan penetralan dengan larutan $\mathrm{NaOH}$ serta penyaringan, maka volume akhir larutan tidak sama dengan volume awal tapi berkisar antara 600-700 ml, 
begitu pula untuk berat contoh 25 gram

mendapatkan volume akhir di bawah volume dengan penambahan asam sulfat $250 \mathrm{ml}$, awal yaitu antara $240 \quad-245 \quad \mathrm{ml}$.

Tabel 2. Volume larutan hasil hidrolisis asam serat sagu

\begin{tabular}{lccccc}
\hline Jenis Serat & $\begin{array}{c}\text { Berat } \\
\text { Contoh (gr) }\end{array}$ & $\begin{array}{c}\text { Konsentrasi } \\
\mathbf{H}_{\mathbf{2}} \mathbf{S O}_{\mathbf{4}} \mathbf{( N )}\end{array}$ & $\begin{array}{c}\text { Volume } \mathbf{H}_{\mathbf{2}} \mathbf{S O}_{\mathbf{4}} \\
(\mathbf{m l})\end{array}$ & $\begin{array}{c}\text { Lama Hidrolisis } \\
(\mathbf{J a m})\end{array}$ & $\begin{array}{c}\text { Volume larutan } \\
(\mathbf{m l})\end{array}$ \\
\hline Sagu Baruk & & & & 2 & 625 \\
& 75 & 0,5 & 750 & 3 & 600 \\
& 25 & 0,5 & 750 & 4 & 240 \\
& 75 & 0,5 & 250 & 2 & 575 \\
& 75 & 1,0 & 750 & 3 & 550 \\
& 25 & 1,0 & 750 & 4 & 245 \\
& 75 & 1,0 & 250 & 2 & 600 \\
Sagu Rumbia & 1,5 & 750 & 3 & 600 \\
& 75 & 1,5 & 750 & 4 & 245 \\
& 25 & 1,5 & 250 & 2 & 700 \\
& 75 & 0,5 & 750 & 3 & 245 \\
& 75 & 0,5 & 750 & 4 & 700 \\
& 25 & 0,5 & 250 & 2 & 670 \\
& 75 & 1,0 & 750 & 3 & 650 \\
& 75 & 1,0 & 750 & 4 & 700 \\
& 25 & 1,0 & 250 & 2 & 240 \\
\hline
\end{tabular}

Hasil ini menunjukkan bahwa ada pengurangan volume ekstrak cairan yang dihasilkan dibandingkan dengan volume awal larutan sebelum proses hidrolisis. Adanya pengurangan volume larutan/cairan pada akhir proses disebabkan oleh sebagian larutan tertinggal dalam butiran serat sagu dan tidak ikut tersaring ke dalam larutan ekstrak. Ini ditandai dengan butiran serat sagu yang tetap basah setelah dibiarkan 2 jam setelah proses penyaringan, juga sebagian cairan melekat pada kertas saring.

Dari Tabel 2 diatas diketahui bahwa perbedaan konsentrasi asam sulfat yang ditambahkan memperlihatkan perbedaan volume akhir, dimana semakin tinggi konsentrasi larutan asam sulfat yang ditambahkan, maka volume akhir cenderung meningkat atau semakin tinggi. Hal ini disebabkan karena semakin tinggi konsentrasi asam sulfat yang ditambahkan, maka semakin banyak volume larutan $\mathrm{NaOH}$ $20 \%$ yang dibutuhkan untuk proses penetralan sehingga dengan sendirinya akan mempengaruhi volume akhir cairan/larutan ekstrak.

\section{Pengaruh Konsentrasi Asam dan Lama} Hidrolisis Terhadap Kadar Gula Serat Sagu

Setelah melalui proses hidrolisis dengan penambahan asam sulfat $0,5 \mathrm{~N} ; 1,0 \mathrm{~N}$ dan $1,5 \mathrm{~N}$ serta lama hidrolisis yang bervariasi, maka diperoleh kadar gula serat sagu seperti tercantum pada Tabel 2. 
Untuk mendapatkan hasil optimal dalam proses hidrolisis serat sagu khususnya jumlah gula, maka telah dilakukan penelitian penggunaan asam sulfat dengan konsentrasi rendah yaitu $0,5 \mathrm{~N} ; 1,0 \mathrm{~N} ; 1,5 \mathrm{~N}$ dan divariasikan dengan lama hidrolisis 2 jam, 3 jam dan 4 jam.

Pembuatan etanol dari bahan baku limbah serat/empulur sagu akan dipengaruhi oleh berbagai faktor, dan untuk mendapatkan hasil yang optimal, maka salah satu faktor yang sangat berpengaruh dalam proses hidrolisis ialah konsentrasi asam. Penggunaan asam dengan konsentrasi tinggi atau konsentrasi rendah akan memberikan hasil yang bervariasi. Beberapa penelitian sebelumnya menyatakan bahwa penggunaan asam dengan konsentrasi tinggi akan memberikan kadar gula yang tinggi setelah melalui tahapan hidrolisis, namun mempunyai kelemahan dari segi biaya dan lingkungan[13]. Sebaliknya penelitian lain menyatakan bahwa penggunaan asam sulfat dengan konsentrasi rendah $(0,3 \mathrm{~N})$ akan memberikan hasil optimal[3].

Penggunaan asam sulfat konsentrasi rendah juga menghemat biaya karena ongkos produksi lebih rendah dan murah, serta dampak terhadap lingkungan tidak seberat jika mengunakan asam sulfat dengan konsentrasi tinggi. Selain faktor konsentrasi asam sulfat, maka faktor lama hidrolisis terhadap serat selulosa mempengaruhi kadar gula yang dihasilkan. Hasil penelitian penulis terhadap lama hidrolisis terhadap serat selulosa sabut kelapa menunjukkan semakin lama waktu hidrolisis (6 jam), maka kadar gula yang dihasilkan akan semakin tinggi,akan tetapi penelitian lain menyatakan bahwa pada lama hidrolisis 2 jam dihasilkan kadar gula optimal (tertinggi) dan jika hidrolisis dilakukan diatas 2 jam (120 menit), maka kadar gula yang dihasilkan cenderung menurun[18].

Hasil penelitian dengan perlakuan penggunaan asam sulfat berbagai konsentrasi dan lama hidrolisis menunjukkan pada penggunaan konsentrasi asam sulfat $0,5 \mathrm{~N}$ dan lama hidrolisis 2 jam, baik serat sagu baruk maupun serat sagu rumbia menghasilkan kadar gula rendah $(3,25 \%$ dan $10,50 \%$, akan tetapi dengan meningkatnya konsentrasi asam sulfat serta waktu hidrolisis selama 3 jam, maka kadar gula yang dihasilkan mencapai angka maksimal/optimal $(12,90 \%$ pada serat sagu baruk dan $13,90 \%$ pada serat sagu rumbia). Pada proses hidrolisis 4 jam kadar gula yang di hasilkan mulai menurun $(4,92 \%$ pada serat sagu baruk dan 5,56\% pada serat sagu rumbia). Dari Tabel 2 diatas, kadar gula tertinggi hasil hidrolisis diperoleh pada konsentrasi asam sulfat 1,5 N dan lama hidrolisis 3 jam yakni 14,50\% (serat sagu rumbia).

Tingginya kadar gula yang diperoleh pada hidrolisis asam sulfat 1,5 N terjadi karena pada konsentrasi asam sulfat 1,5 N, maka proses degradasi/peruraian selulosa (alfa selulosa dan hemiselulosa) serat sagu optimal, dimana komponen asam dapat secara optimal memutuskan rantai ikatan alfa maupun beta selulosa sehingga 
terputus/terurai menjadi monomer-monomer gula tunggal, yakni glukosa (selulosa tersusun oleh monosakarida diantaranya glukosa dengan ikatan alfa dan beta ). Pada konsentrasi asam sulfat $0,5 \mathrm{~N}$ ternyata hidrolisis tidak berlangsung optimal karena kadar gula relatif rendah. Hal ini diduga asam belum optimal atau tidak cukup untuk menguraikan/memutuskan ikatan alfa dan beta glukosa pada serat sagu. Disamping itu, konsentrasi asam yang kurang tidak mempu memecahkan komponen lain yang merekatkan antar selulosa maupun lignin yang menyatukan sel selulosa yang satu dengan yang lain. Pada konsentrasi larutan asam sulfat 1,5 $\mathrm{N}$ dalam proses hidrolisis gugus $\mathrm{H}^{+}$dari asam akan mengubah gugus serat sagu menjadi gugus radikal bebas dan gugus radikal bebas serat sagu yang kemudian akan berikatan dengan gugus $\mathrm{OH}^{-}$ dari air, dan bereaksi pada suhu $120{ }^{\circ} \mathrm{C}$ (suhu autoklave) menghasilkan gula tinggi. Sebaliknya pada konsentrasi asam sulfat rendah $(0,5$ dan $1,0 \mathrm{~N})$, kebutuhan $\mathrm{H}^{+}$dari asam belum mencukupi sehingga tidak banyak terbentuk radikal bebas dari serat sagu dan gula yang dihasilkan belum maksimal.

Waktu hidrolisis 3 jam merupakan waktu optimal terjadinya hidrolisis, dimana selulosa yang ada dalam serat sagu semakin lama bersentuhan dengan asam yang ditambahkan. Selain itu, proses dekomposisi selulosa terurai menjadi karbohidrat (gula) semakin banyak. Faktor lain yaitu suhu bertekanan yang dilakukan dalam jangka waktu yang optimum pada proses hidrolisis sangat berpengaruh terhadap perombakan bahan-bahan yang melindungi atau mengikat komponen selulosa dalam serat menjadi monosakarida-monosakarida bebas yang tidak terikat, baik alfa maupun beta glukosa. Glukosa-glukosa yang telah diputuskan rantai ikatan alfa maupun beta akan lebih mudah diubah menjadi etanol oleh ragi. Sebaliknya jika waktu hidrolisis pendek (2 jam), maka proses penguraian selulosa menjadi gula sederhana (monosakarida) tidak optimal, karena pada saat belum semua selulosa dalam serat sagu terdekomposisi menjadi glukosa, proses telah terhenti. Sebaliknya jika waktu hidrolisis terlalu lama (4 jam), maka glukosa (gula) akan terdegradasi menjadi hydroxymethylfurfural dan bereaksi lebih lanjut membentuk asam formiat, sehingga menyebabkan kadar gula menurun.

\section{Fermentasi Gula Menjadi Etanol}

Angka kuantitatif proses fermentasi etanol/bioetanol dari gula hasil hidrolisis serat sagu oleh ragi menjdi etanol, tercantum pada Tabel 3. Data Tabel 3 menunjukkan kadar etanol tertinggi yakni $13,60 \%$, pada penambahan larutan asam sulfat 1,0 N dan lama hidrolisis 3 jam, sedangkan kadar ertanol terendah pada proses penambahan larutan asam sulfat $0,5 \mathrm{~N}$ dan lama hidrolisis 2 jam yaitu 2,43\%. Kadar etanol meningkat seiring dengan kenaikkan persentase kadar gula. Semakin tinggi kadar gula serat sagu hasil hidrolisis, maka semakin tinggi kandungan etanol yang diperoleh setelah proses fermentasi oleh ragi. Proses 
fermentasi gula menjadi etanol oleh ragi dipengaruhi oleh kadar gula dalam larutan.
Semakin tinggi kadar gula dalam larutan, maka semakin optimal aktifitas

Tabel 3. Kadar gula dan etanol serat sagu

\begin{tabular}{lcccc}
\hline Jenis Serat & $\begin{array}{c}\text { Konsentrasi } \\
\mathbf{H}_{\mathbf{2}} \mathbf{S O}_{\mathbf{4}} \mathbf{( N )}\end{array}$ & $\begin{array}{c}\text { Lama Hidrolisis } \\
(\mathbf{J a m})\end{array}$ & $\begin{array}{c}\text { Kadar Gula } \\
(\%)\end{array}$ & $\begin{array}{c}\text { Kadar Etanol } \\
(\%)\end{array}$ \\
\hline Sagu Baruk & 0,5 & 2 & 3,25 & 2,43 \\
& 0,5 & 3 & 5,26 & 4,18 \\
& 0,5 & 4 & 5,94 & 3,47 \\
& 1,0 & 2 & 5,60 & 4,77 \\
& 1,0 & 3 & 12,90 & 11,36 \\
& 1,0 & 4 & 4,92 & 2,57 \\
& 1,5 & 2 & 6,76 & 5,73 \\
& 1,5 & 3 & 10,90 & 10,53 \\
& 1,5 & 4 & 5,50 & 3,40 \\
& 0,5 & 2 & 10,50 & 9,46 \\
& 0,5 & 3 & 11,90 & 11,53 \\
& 0,5 & 4 & 10,20 & 6,37 \\
& 1,0 & 2 & 9,70 & 8,23 \\
& 1,0 & 3 & 13,80 & 13,60 \\
& 1,0 & 4 & 6,17 & 4,13 \\
& 1,5 & 2 & 14,40 & 12,55 \\
& 1,5 & 3 & 14,50 & 12,99 \\
& 1,5 & 4 & 5,56 & 5,56 \\
\hline
\end{tabular}

mikroorganisme khamir merombak gula menjadi etanol. Hasil pengamatan pada Tabel 4 memperlihatkan apabila kadar gula dalam larutan serat sagu diatas $10 \%$, maka mikroorganisme khamir (ragi) akan optimal melakukan fermentasi/merubah gula menjadi etanol, bahkan angka persentasenya diatas $90 \%$. Sebaliknya jika kandungan gula dalam larutan serat sagu di bawah $10 \%$ ternyata mikroorganisme tidak optimal merombak gula menjadi etanol dan angka persentase keberhasilan fermentasi dibawah 90\%.

Keberhasilan mikroorganisme khamir dalam melakukan fermentasi gula menjadi etanol dipengaruhi oleh berbagai faktor antara lain $\mathrm{pH}$ larutan dan ketersediaan nutrien. Pada larutan hasil hidrolisis serat sagu dengan kandungan gula tinggi juga ketersediaan nutrisi tinggi sehingga hampir semua khamir/ragi yang ditambahkan melakukan aktifitas fermentasi merubah gula menjadi etanol dan dengan demikian kadar etanol tinggi. Sebaliknya apabila kadar gula dalam larutan hasil hidrolisis serat sagu rendah, maka kandungan nutrisi dalam larutan tersebut rendah. Sehingga ada sebagian ragi tidak mendapatkan makanan/nutrisi untuk merubah gula menjadi alcohol, bahkan sebagian mikroorganisme akan mengubah etanol menjadi asam asetat dan ini mengakibatkan penurunan kadar etanol.

\section{Rendemen}

Dari Tabel 4, terlihat bahwa rendemen etanol yang dihasilkan berkisar antara 32,85 
- 81,63\%. Rendemen tertinggi diperoleh pada proses hidrolisis 4 jam dengan penambahan larutan asam sulfat $1,5 \mathrm{~N}$ dan terendah pada perlakuan penambahan asam sulfat1, $0 \mathrm{~N}$ dan lama hidrolisis 2 jam.

Data pada Tabel 4 juga menunjukkan semakin tinggi konsentrasi larutan asam sulfat yang ditambahkan dan semakin lama waktu hidrolisis, maka rendeman etanol/bioetanol yang dihasilkan semakin tinggi. Hal ini terjadi karena pada awal destilasi volume larutan yang dihidrolisis dengan konsentrasi asam sulfat tinggi relatif lebih tinggi daripada volume larutan awal cairan yang diproses dengan asam sulfat konsentrasi rendah (perlakuan 2 dan 3 jam lama hidrolisis).
Tinggi atau rendahnya persentase rendemen larutan etanol yang dihasilkan ditentukan oleh sistem pemanasan pada tahap penyulingan/destilasi dan lama proses destilasi. Semakin tinggi suhu pemanasan dan semakin lama proses destilasi, maka semakin banyak rendemen yang diperoleh. Sebaliknya semakin rendah suhu pemanasan dan waktu penyulingan yang tidak lama, maka rendemen yang di hasilkan relatif rendah. Dalam proses destilasi etanol, faktor suhu sangat berperan. Agar hasil destilasi etanol optimal, maka selama proses destilasi diusahakan agar suhu minimum dan sebaiknya suhu dibawah $100^{\circ} \mathrm{C}$.

Tabel 4. Rendemen kadar etanol

\begin{tabular}{lccccc}
\hline Jenis Serat & $\begin{array}{c}\text { Konsentrasi } \\
\mathbf{H}_{\mathbf{2}} \mathbf{S O}_{\mathbf{4}} \mathbf{( N )}\end{array}$ & $\begin{array}{c}\text { Lama } \\
\text { Hidrolisis } \\
\text { (Jam) }\end{array}$ & $\begin{array}{c}\text { Volume larutan } \\
\mathbf{( m )}\end{array}$ & $\begin{array}{c}\text { Volume } \\
\text { Etanol }(\mathbf{m l})\end{array}$ & $\begin{array}{c}\text { Rendemen } \\
(\%)\end{array}$ \\
\hline Sagu Baruk & 0,5 & 2 & 625 & 320 & 51,20 \\
& 0,5 & 3 & 600 & 340 & 56,00 \\
& 0,5 & 4 & 240 & 180 & 75,00 \\
& 1,0 & 2 & 575 & 250 & 43,47 \\
& 1,0 & 3 & 550 & 364 & 66,18 \\
& 1,0 & 4 & 245 & 190 & 77,55 \\
Sagu & 1,5 & 2 & 600 & 270 & 45,00 \\
Rumbia & 1,5 & 3 & 600 & 360 & 60,00 \\
& 1,5 & 4 & 245 & 200 & 81,63 \\
& 0,5 & 2 & 650 & 340 & 52,30 \\
& 0,5 & 3 & 700 & 370 & 52,85 \\
& 0,5 & 4 & 245 & 185 & 75,51 \\
& 1,0 & 2 & 700 & 230 & 32,85 \\
& 1,0 & 3 & 670 & 400 & 59,70 \\
& 1,0 & 4 & 240 & 190 & 79,16 \\
& 1,5 & 2 & 650 & 320 & 49,23 \\
& 1,5 & 3 & 700 & 400 & 57,14 \\
& 1,5 & 4 & 240 & 180 & 75,00 \\
\hline
\end{tabular}




\section{KESIMPULAN}

Serat/ampas sagu baruk dan sagu rumbia dapat diolah menjadi etanol dengan kadar alkohol antara 2,43 - 11,36 \% untuk serat sagu baruk dan 4,13 - 13,60\% pada serat sagu rumbia. Kadar gula tertinggi diperoleh pada serat/ampas sagu rumbia dengan penambahan asam sulfat $1,5 \mathrm{~N}$ dan lama hidrolisis 3 jam yakni $13,90 \%$. Kadar alkohol tertinggi didapatkan pada serat/ampas sagu rumbia dengan penambahan asam sulfat $1 \mathrm{~N}$ dan lama hidrolisis 3 jam yakni $13,60 \%$

\section{DAFTAR PUSTAKA}

1. Abner L, Miftahorrahman. Keragaman industri sagu Indonesia. Warta Penelitian dan Pengembangan Tanaman Industri. Vol 8 No 1 Juni 2002. 2002.

2. Akyuni D. Pemanfaatan pati sagu (metroxylon sp.) untuk pembuatan sirup glukosa menggunakan -amilase dan amiloglukosidase. Skripsi. Fakultas Teknologi Pertanian, IPB, Bogor. 2004.

3. Anggraeni PZ, Addarojah DD, Anggoro. Hidrolisis selulosa eceng gondok (Eichhornia crassipe) menjadi glukosa dengan katalis arang aktif tersulfonasi. Jurnal Teknologi Kimia dan Industri. Vol. 2, No. 3. Hal 63-69. 2013.

4. Clark TA., Mackie KL. Fermentation inhibitors in wood hydrolysates derived from the softwood Pinus radiata. Journal of Chemical Technology and Biotechnology. 34.2: 101110. 1984.

5. Dhiputra K., Made I., Jonatan N, Ekayuliana A. Pemanfaatan Ampas Ela Sagu Sebagai Bioetanol untuk Kebutuhan Bahan Bakar Rumah Tangga di Provinsi Papua, Proceeding Seminar Nasional Tahunan
Teknik Mesin XIV (SNTTMXIV). Banjarmasin. 2015.

6. Hartoto L. Petunjuk Laboratorium Teknologi Fermentasi. Depdikbud. PAU IPB. Bogor. 1992

7. Haryanto B, Pangloli P. Potensi dan Pemanfaatan Sagu. Kanisius. 1992.

8. Islamiyati R. Kandungan nutrisi campuran ampas sagu (Metroxilon sago) dan feses broiler yang difermentasi dengan berbagai level EM4. Seminar Nasional Teknologi Peternakan dan Veteriner. Fakultas Peternakan Universitas Hasanuddin. Makassar. 2009.

9. Khairunnisah. Produksi bioetanol dari ampas sagu (Metroxylon $s p$ ) melalui proses pretreatment dan metode simultaneous saccharification fermentation (SSF). Tesis. Jurusan Kimia FMIPA Universitas Andalas. Padang. 2014.

10. Kiat LJ. Preparation and characterization of carboxymethyl sago waste and its hydrogel. PhD Thesis. School of Graduate Studies, Universiti Putra Malaysia. 2006.

11. Sukria HA. Kualitas protein dan komposisi asam amino ampas sagu hasil fermentasi Aspergillus niger dengan penambahan urea dan zeolit. Jurnal IImu Pertanian Indonesia. 20(2), 124-130. 2015.

12. Yolanda A, Muria SR, Chairul. Pembuatan bioetanol dari limbah padat sagu menggunakan enzim selulase dan yeast Saccharomyces cerevisiae dengan proses simultaneous sacharificatian and fermentation (SSF) dengan variasi konsentrasi substrat dan volume inokulum. Jurnal Online Mahasiswa (JOM) Bidang Teknik dan Sains Vol 1, No 1. 2014.

13. Wiratmaja IG, Kusuma IW, Winaya SIN. Pembuatan etanol generasi kedua dengan memanfaatkan limbah rumput laut Eucheuma cottonii sebagai bahan baku, Jurnal IImiah Teknik Mesin .Vol. 5 No.1: (7584). 2011. 